\title{
Peningkatan Pembelajaran Melalui Situs Media Online dengan Metode Blended Learning Pada Masyarakat Desa Bojongcae
}

Indri Arrafi Juliannisa

Universitas Pembangunan Nasional Veteran Jakarta

arrafi.juliannisa@gmail.com

Key word:

Education;

E-learning;

Blended learning

\section{Kata Kunci}

Pendidikan;

E-learning;

Blended learning

\section{Abstract}

This community service activity is intended to provide more knowledge to the residents of Bojongcae- Lebak Regency, especially for parents, and children and teenagers who relied on manual and limited teaching material for education with increasing the ability of partner groups in the world of education. The partner groups in this study are housewives who are members of the PKK group, and teenagers who have the ability to speak English better than housewives and other teenagers. The material provided in this community service program is internet based using social media instragram with the account name "ayokita.belajar". The material chosen by the service team are learning of English language and learning of skills related to daily needs, the selection of material and social media was agreed by the partner group, with this activity the partner group is expected to be able to provide teaching materials more creative, innovative and easily understood. Moreover, addition of knowledge about study by e-learning is expected that the process of providing subject matter can be more modern and follow more sophisticated technological developments. The result of this community service activity is that partner groups can create a training or learning activity with English-language material and training videos to improve their daily skills. Measurement of learning with social media have done by way of children and adolescents given questions about material that has been uploaded on social media Instagram.

\section{Abstrak}

Kegiatan pengabdian masyarakat ini dimaksudkan untuk memberikan pengetahuan lebih kepada pada warga Desa Bojongcae- Kabupaten Lebak terutama untuk orang tua, serta anak-anak dan remaja desa yang selama ini hanya mengandalkan pemberian materi pelajaran secara manual dan terbatas ataupun para warga yang harus mengalami putus sekolah. Kegiatan pengabdian masyarakat ini bekerjasama dengan kelompok mitra ibu-ibu PKK Desa Bojongcae, sasaran kegiatan ini adalah kelompok mitra dan para warga desa untuk meningkatkan kemampuan dalam dunia pendidikan, karena pendidikan sangat berhubungan erat terhadap ekonomi, melalui pendidikan kita dapat memutuskan rantai kemiskinan. Adapun alasan diadakan kegiatan ini karena banyaknya masyarakat yang putus sekolah yang terkendala biaya dan jarak untuk memperoleh pendidikan. Materi yang diberikan kegiatan ini berbasis internet dengan menggunakan social media instragram dengan akun "ayokita.belajar". Materi yang dipilih adalah bahasa inggris dan keterampilan yang berhubungan dengan kebutuhan sehari-hari, yang telah disetujui oleh kelompok mitra, pemberian materi dilakukan seminggu tiga kali. Untuk mengevaluasi hasil kegiatan ini dilakukannya test secara lisan selama 2 minggu sekali, dan diadakan pertemuan 1 minggu sekali untuk melakukan pembelajaran secara 
langsung, guna mengukur apakah materi dapat dimengerti, hasilnya warga sangat antusias dan berharap ada kegiatan lanjutan.

\section{PENDAHULUAN}

Modal manusia adalah faktor yang sangat penting dalam menentukan produktivitas suatu perekonomian. Kualitas modal manusia yang berbeda diyakini dapat menyebabkan dua perekonomian yang memiliki jumlah tenaga kerja, modal fisik, sumber daya alam dan teknologi yang identik menghasilkan output yang berbeda. Peran penting modal manusia dijelaskan dalam Teori Human Capital. Teori Human Capital mengasumsikan bahwa pendidikan dapat meningkatkan kualitas dari segi pendidikan, kesehatan dan penghasilan seorang pekerja di masa yang akan datang. Keputusan seseorang untuk melanjutkan pendidikan ke jenjang yang lebih tinggi merupakan suatu bentuk investasi sekaligus sebagai opportunity cost (pilihan terbaik) dengan harapan orang tersebut dapat memperoleh kesejahteraan yang lebih tinggi sebagai imbalan dari pendidikan yang di miliki, serta taraf kesejahteraan yang dimiliki juga menjadi faktor penentuan modal manusia (Aditiya, 2016).

Program peningkatan modal manusia di Indonesia, kini telah didukung oleh pemerintah dengan dibentuknya Sustainable Development Goals (SDG's), peningkatan modal manusia ini dapat mendukung tinggginya angka Indeks Pembangunan Manusia ( IPM). Menurut United Nations Development Programme (UNDP), dalam Indeks Pembangunan Manusia (IPM) terdapat tiga indikator komposit yang digunakan untuk mengukur pencapaian rata-rata suatu negara dalam pembangunan manusia, yaitu: lama hidup, yang diukur dengan angka harapan hidup ketika lahir; pendidikan yang diukur berdasarkan rata-rata lama bersekolah dan angka melek huruf penduduk usia 15 tahun ke atas; standar hidup yang diukur dengan pengeluaran perkapita yang telah disesuaikan menjadi paritas daya beli. Nilai indeks ini berkisar antara 0-100. Pengertian IPM yang dikeluarkan oleh UNDP yang menyatakan bahwa Indeks Pembangunan Manusia (IPM) atau Human Development Indeks (HDI) merupakan salah satu pendekatan untuk mengukur tingkat keberhasilan pembangunan manusia (Suliswanto, 2010).

Terdapat salah satu desa yang terdapat di Kabupaten lebak, yang memiliki angka IPM dengan indikator harapan sekolah yang rendah, yakni Desa Bojongcae. Desa Bojongcae bukan merupakan wilayah pesisir, melainkan wilayah dataran rendah yang terletak diluar 
kawasan perhutanan. Luas Desa Bojongcae adalah $188 \mathrm{Ha}$, jarak desa ke wilayah kecamatan adalah $2 \mathrm{Km}$, sedangkan jarak Desa ke ibukota kabupaten adalah $8 \mathrm{Km}$. Jumlah penduduk desa Bojongcae sampai dengan tahun 2017 adalah 3524 jiwa, dengan kepadatan penduduk sebesar 1874 jiwa $/ \mathrm{km}^{2}$. Jumlah penduduk yang berprofesi sebagai petani sebanyak 183 orang, sebagai buruh tani sebanyak 268 orang, sebagai nelayan sebanyak 1 orang, buruh nelayan juga 1 orang, PNS sebanyak 16 orang, home industri sebanyak 10 orang, berdagang sebanyak 58 orang dan berprofesi sebagai jasa-jasa lainnya sebanyak 54 orang. Di Desa Bojongcae Hanya terdapat 1 Sekolah Dasar (SD) sehingga warga kesulitan untuk melanjutkan pendidikan ke jenjang selanjutnya dan sebagian besar pendidikan terakhir warga adalah Sekolah Menengah Pertama (SMP). Hal ini akan memperlambat pembangunan untuk desa tersebut, karena desa tersebut memiliki produktifitas SDM (Sumber Daya Manusia) yang redah, selain itu tenaga pengajar yang ada di desa tersebut masih menggunakan metode-metode belajar yang manual dan kurang menarik minat untuk tekun dalam belajar, oleh sebab itu butuhkan keperdulian dari pihak-pihak tertentu untuk dapat membantu mensukseskan pendidikan pada warga Desa Bojongcae, terutama untuk generasi-generasi muda, dalam hal memberikan inovasi dalam bidang pendidikan dengan menggunakan kecanggihan teknologi saat ini (BPS Cibadak, 2017).

Jarak tempuh antara rumah warga dan sekolah membuat para warga ( pihak orangtua dan murid ) menjadi malas untuk menempuh pendidikan, serta keahlian yang dimiliki oleh para pengajar yang kurang menunjang dalam proses pembelajaran membuat warga kurang termotivasi dalam dunia pendidikan, selain itu warga kurang mengetahui akan dunia pendidikan online dan banyaknya situs-situs internet yang dapat diperdayagunakan untuk menempuh pendidikan baik itu formal maupun informal (Sugianto, Permadhi, \& Juliannisa, 2018).

Oleh sebab itu melalui program pengabdian masyarakat ini akan melakukan metode pembelajaran berbasis internet dengan menggunakan situs online sosial media, yakni instagram. Dengan metode Blended Learning, yaitu metode gabungan antara pembelajaran tatap muka dan secara virtual. Blended Learning adalah sebuah kemudahan pembelajaran yang menggabungkan berbagai cara penyampaian, model pengajaran, dan gaya pembelajaran, memperkenalkan berbagai pilihan media dialog antara fasilitator dengan orang yang mendapat pengajaran. 


\section{METODE PEMECAHAN MASALAH}

Menurut Harding, Kaczynski dan Wood yang dikutip dalam Charman, blended learning merupakan pendekatan pembelajaran yang mengintegrasikan pembelajaran tradisonal tatap muka dan pembelajaran jarak jauh yang menggunakan sumber belajar online dan beragam pilihan komunikasi yang dapat digunakan oleh kelompok mitra.

Adapun hal-hal yang menjadi karakteristik dari blended learning antara lain:

a. Pembelajaran yang menggabungkan berbagai cara penyampaian, model pengajaran, gaya pembelajaran, dan serta berbagai media berbasis teknologi yang beragam.

b. Sebagai sebuah kombinasi pengajaran langsung (face to face), belajar mandiri, dan belajar mandiri via online

c. Aspek pembelajaran : Bahasa indonesia, bahasa inggris, matematika, dan keterampilan.

d. Pembelajaran yang didukung oleh kombinasi efektif dari cara penyampaian, cara mengajar dan gaya pembelajaran.

e. Guru / para pengajar dan orangtua peserta belajar memiliki peran yang sama penting, guru sebagai fasilitator, dan orangtua sebagai pendukung.
Asusmsinya, penerapan sistem untuk pembelajaran menggunakan metode Blended learning bisa menjadi pilihan yang bagus untuk proses pengajaran). (

Hidayat, Rahmatan, \& Khairil, 2016).

Target dalam pengabdian kepada masyarakat ini berfungsi untuk memberikan pemecahan masalah (solusi) terhadap permasalahan yang terjadi pada mitra, yaitu berupa:

1. Pengajar professional dibidangnya, dan menggunakan media online seperti : instagram.

2. Tampilan pembelajaran akan menggunakan gambar dan video,metode pembelajaran akan dilakukan secara online, berdasarkan peminat yang ada.

3. Materi dasar Bahasa Inggris menjadi materi utama dalam pembelajaran BLENDED LEARNING.

4. Materi tentang keterampilan juga akan menjadi materi tambahan dalam metode pembelajaran ini.

5. Akan ada hasil penilaian terhadap materi yang diberikan. (Rohdiani \& Rakhmawati, 2017)

Metode yang diterapkan dalam pelaksanaan kegiatan ini adalah pelatihan terstruktur. Maksud dari metode ini adalah metode ceramah, diskusi informasi dan dilanjutkan dengan penerapan secara langsung dengan menggunakan media 
digital. Materi ceramah dan diskusiinformasi dimaksudkan memberikan pengetahuan wawasan tentang pendidikan dan dunia online. Adapun proses metode pelaksanaannya sebagai berikut :

1. Perencanaan kegiatan yang akan dilakukan meliputi identifikasi kebutuhan materi pembelajaran, identifikasi potensi dan kelemahan yang ada, menentukan jalan keluar dan kegiatan yang akan dilakukan, dan membuat pengorganisasian kegiatan pembelajaran tersebut.

2. Pelaksanaan kegiatan dilaksanakan bersama-sama oleh kelompok mitra untuk pengenalan metode blended learning dan sasaran lainnya adalah warga desa yang putus sekolah dasar, sedangkan tim pengabdian akan bertindak sebagai fasilitator dan pemateri.

3. Monitoring dan evealuasi kegiatan dalam proses ini juga dilakukan tim pengabdi.
Untuk mencapai tujuan yang diharapkan, maka pelaksanaan pelatihan pembelajaran melalui media ini menggunakan 3 metode pembelajaran, yaitu:

1. Tutorial: Instruktur menjelaskan tentang tata cara membuat media pembelajaran online yang dimaksud dengan menggunakan alat bantu LCD sehingga peserta dapat memahami tanpa harus mendengarkan teori atau membaca modul terlebih dulu.

2. Praktek Mandiri Anggota mitra bisa melakukan praktek menggunakan Handphone masing berbasis android / IOS

3. Tanya Jawab Peserta dapat langsung bertanya kepada Tim Pengabdian pada masyarakat yang mendampingi mereka selama kegiatan berlangsung Rangkuman rencana kegiatan dijelaskan pada table 1. 
Tabel 1. Perencanaan Kegiatan Pengabdian Masyarakat

\begin{tabular}{|c|c|c|}
\hline Kegiatan & Kriteria & Indikator Keberhasilan \\
\hline Perencanaan Kegiatan & $\begin{array}{l}\text { Identifikasi kebutuhan materi } \\
\text { yang ada, identifikasi potensi } \\
\text { dan kelemahan yang ada, } \\
\text { serta menentukan jalan } \\
\text { keluar dan kegiatan yang } \\
\text { akan dilakukan kedepannya. }\end{array}$ & $\begin{array}{l}\text { Meningkatkan pengetahuan dan } \\
\text { pemahaman tentang metode pembelajaran: } \\
\text { a. Mampu mendeteksi kebutuhan sendiri } \\
\text { dalam hal peningkatan pengetahuan } \\
\text { dan minat belajar. } \\
\text { b. Masyarakat mampu mendeteksi } \\
\text { kelemahan dirinya dalam segi } \\
\text { pendidikan yang telah dilakukan } \\
\text { dan menyusun rencana perbaikan. }\end{array}$ \\
\hline Pelaksanaan kegiatan & $\begin{array}{l}\text { Mitra mampu menjalankan } \\
\text { program pendidikan secara } \\
\text { online dan mampu } \\
\text { menerapkan pengetahuan itu } \\
\text { secara berkelanjutan. }\end{array}$ & $\begin{array}{l}\text { a. Motivasi dan mengarahkan melakukan } \\
\text { kegiatan pembelajaran secara online. } \\
\text { b. Memotivasi para orang tua dan generasi } \\
\text { muda untuk bisa menempuh } \\
\text { pendidikan, walaupun dengan jarak } \\
\text { jauh. } \\
\text { c. Motivasi untuk mengembang- } \\
\text { pengetahuan secara formal dan } \\
\text { informal. }\end{array}$ \\
\hline
\end{tabular}

\section{HASIL}

Kegiatan awal pengabdian masyarakat yang diadakan adalah penyuluhan dan pelatihan kepada kelompok ibu-ibu PKK Kelurahan Bojongcae tentang pendidikan berbasis internet, pelatihan berlangsung selama kurang lebih dua jam. Metode pelaksanaan adalah dengan melakukan demonstrasi untuk menggunakan sosial media instagram, terutama bagi beberapa peserta yang masih kurang mengerti untuk mengaplikasikannya.

Pelatihan hanya menggunakan sinyal internet dan handphone berbasis android, materi yang di upload pada situs instagram minimal seminggu sebanyak tiga kali dan merupakan gabungan dari materi pelajaran bahasa inggris dan keterampilan.
Materi bahasa inggris yang diberikn hanyalah materi dasar yang mencangkup kehidupan sehari-hari. Selain itu, untuk membuktikan apakah materi tersebut dapat dimengerti, maka diadakan test selama kurun waktu dua minggu sekali dengan cara test lisan yang diberikan secara langsung oleh tim abdimas yang bekerja sama dengan kelompok mitra, hasil evaluasi atau test dari kegiatan ini yaitu dari 45 peserta yang ikut dalam proses pembelajaran, hanya terdapat 20 peserta yang dapat memahami metode pembelajaran blenden learning, yaitu peserta yang tergolong sebagai siswa sekolah dasar ataupun peserta yang pernah duduk menempuh pendidikan sampai dengan kelas 4 dan 5 sekolah dasar, selain itu kelompok mitra ( ibu-ibu PKK ) pengetahuan akan keterampilan dan 
berbahasa inggris pun bertambah, contohnya saja dalam hal pengenalan diri atau bahasa-bahasa pemasaran.

\section{PEMBAHASAN}

Konsep belajar mandiri pada dasarnya menekankan pada kreatifitas dan inisiatif peserta didik. Akan tetapi pada kondisi tertentu, secara sistematik peserta didik dapat meminta bantuan/bimbingan pada pendidik, disini peran pendidik lebih menekan kan sebagai fasilitator, dengan demikian pembelajaran mandiri adalah pembelajaran yang dilakukan individu secara inisiatif, tanpa bantuan orang lain yang sudah mempunyai perencanaan dalam belajar sehingga hasilnya dapat dievaluasi dalam nilai akhir (Rahman, 2016).

Kegiatan pengabdian masyarakat ini bermitra dengan kelompok ibu-ibu PKK Kelurahan Bojongcae, para ibu-ibu PKK dilatih oleh ketua pengabdian masyarakat untuk dapat menggunakan media online sebagai sarana pembelajaran. Salah satu media sosial yang mudah dimengerti untuk digunakan atas dasar pertimbangan ketua pelaksanaan pengabdian masyarakat dan para ibu-ibu PKK adalah media sosial "Instagram", hal ini dikarenakan anggota mitra lebih sering menggunakan media tersebut untuk mendapatkan informasi dan mudah untuk mentransfer ilmunya ke orang lain jika untuk digunakan sebagai media pembelajaran. Konten yang tersedia di media sosial instagram adalah konten pendidikan bahasa inggris dan konten media keterampilan yang dapat meningkatkan pengetahuan, adapun akun media sosial instagram tersebut adalah “ ayokita.belajar ".

Konten materi berbasis bahasa inggris dan keterampilan merupakan materi atas dasar permintaan kelompok mitra, warga merasa ingin menambah pengetahuan berbahasa inggris dengan cara yang lebih mudah, karena selama ini mereka kesulitan belajar secara langsung dengan beberapa pengajar, sedangkan media keterampilan dipilih karena para anggota mitra merasa membutuhkan ilmu tersebut yang dapat membantu mereka dalam kehidupan sehari-hari. Materi keterampilan berisikan keterampilan memasak, membuat prakarya dan teknikteknik yang memudahkan kehidupan sehari-hari.

Peningkatan pemahaman yang sangat signifikan sangat terlihat pada kelompok mitra tersebut, yakni kelompok mitra dapat mengaplikasikan video kreatifitas tersebut untuk membuka lapangan usaha, kelompok mitra mencoba untuk membuat bisnis sandal rumah yang berbahan dari celana bekas, membersihkan barang-barang dapur berkarat dengan baking soda dan membuat gantungan 
handphone dari botol bekas, selain itu dikarenakan instagram merupakan situs online yang bisa di akses oleh siapapun, akhirnya pada akun mari.belajar dapat diakses oleh orang lain, tidak hanya masyarakat bojongcae saja. Terdapat masyarakat lainnya yang ikut bergabung dan tertarik pada akun tersebut, terbukti dari banyaknya pengikut akun tersebut dan jumlah orang yang menyukai akun tersebut.
Akun ayokita.belajar sangat bermanfaat untuk memberikan ilmu kepada orang lain, tidak hanya untuk masyarakat desa bojongcae namun untuk semua masyarakat yang mengikuti akun tersebut dan menyukai materi-materi yang telah di upload. Berikut merupakan gambar dari kegiatan pembelajaran yang dilakukan dengan kelompok mitra dan entuk materi yang disampaikan.
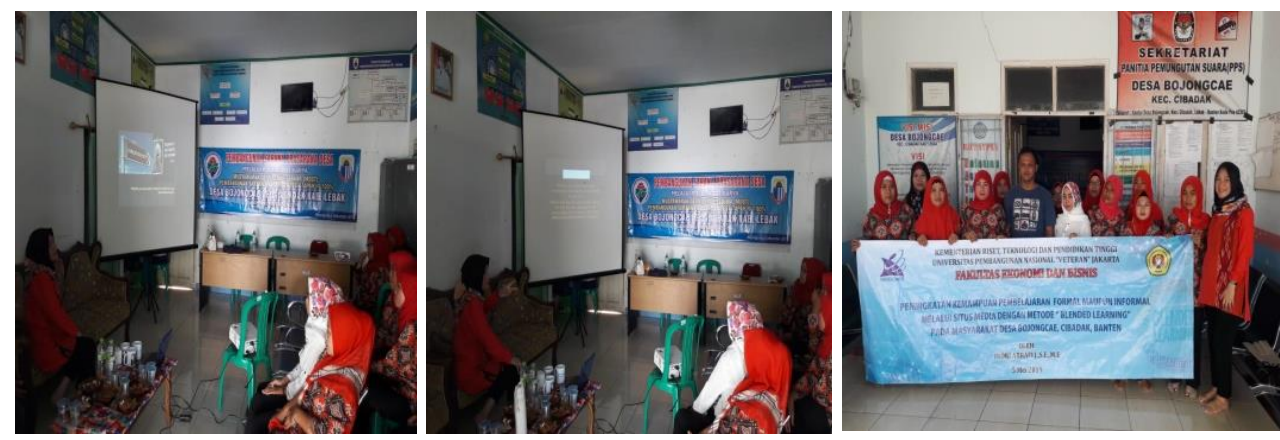

Gambar 1. Tim Pengabdi Sedang Memberikan Pengenalan dan Pelatihan Metode Pembelajaran Blended Learning dan Media Online
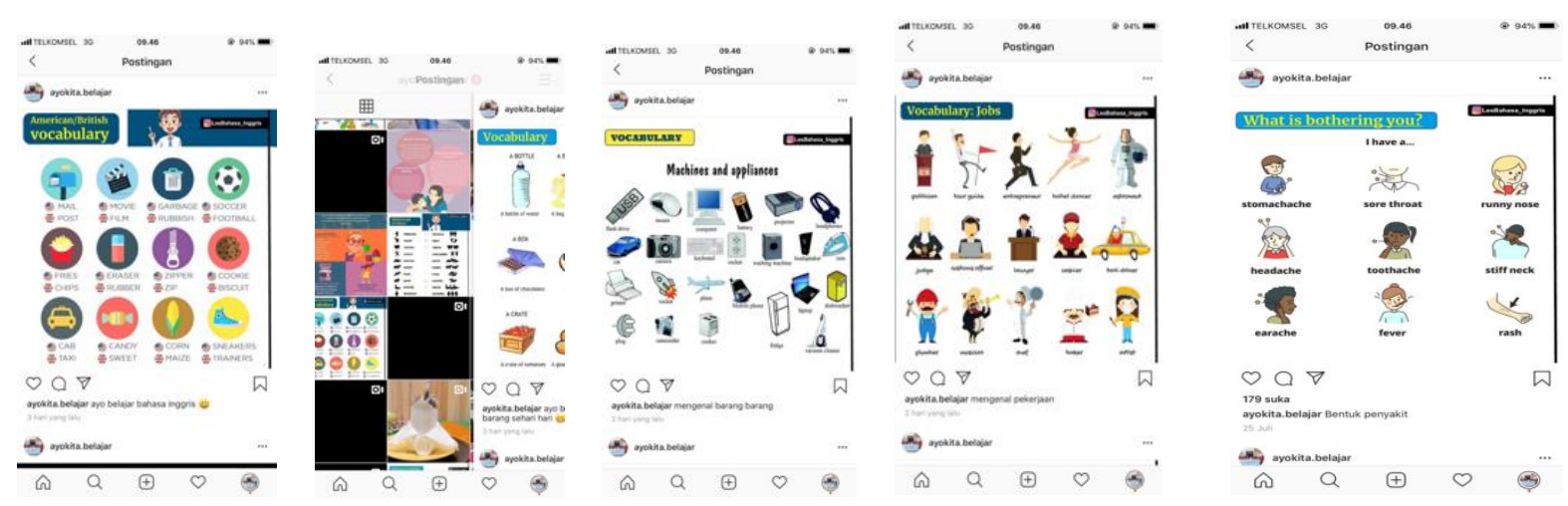

Gambar 2 Materi Yang Telah Diberikan Dalam Social Media Instagram 

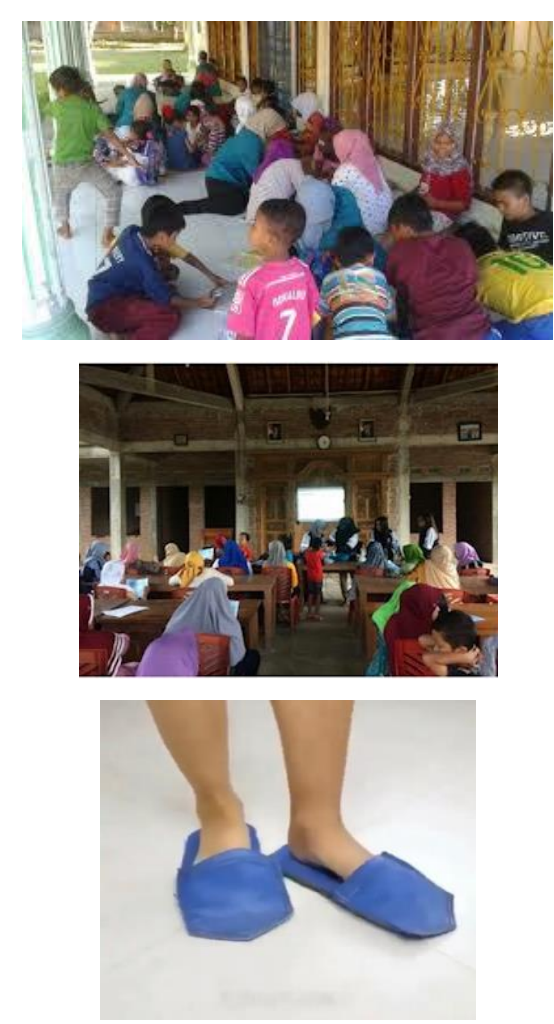

Gambar 3. Kegiatan Pembelajaran Secara Langsung, Evaluasi dan bukti barang jualan.

\section{KESIMPULAN}

Hasil evaluasi atau test dari kegiatan ini yaitu dari 45 peserta yang ikut dalam proses pembelajaran, hanya terdapat 20 peserta yang dapat memahami metode pembelajaran blended learning, yaitu peserta yang tergolong sebagai siswa sekolah dasar ataupun peserta yang pernah duduk menempuh pendidikan sampai dengan kelas 4 dan 5 sekolah dasar, selain itu kelompok mitra ( ibu-ibu PKK ) pengetahuan akan keterampilan dan berbahasa Inggris pun bertambah, contohnya saja dalam hal pengenalan diri atau bahasa-bahasa pemasaran.

Peningkatan pemahaman yang sangat signifikan sangat terlihat pada kelompok mitra tersebut, yakni kelompok mitra dapat mengaplikasikan video kreatifitas tersebut untuk membuka lapangan usaha, kelompok mitra mencoba untuk membuat bisnis sandal rumah yang berbahan dari celana bekas, membersihkan barang-barang dapur berkarat dengan baking soda dan membuat gantungan handphone dari botol bekas.

Berdasarkan hasil evaluasi tersebut, dapat disimpulkan bahwa program pembelajaran berbasis internet ini sangatlah berguna untuk meningkatkan pengetahuan para warga terutama dalam bidang ilmu bahasa Inggris dan keterampilan yang dapat dipergunakan sehari-hari, selain itu metode pembelajaran ini ternyata tidak hanya diminati oleh kelompok mitra saja, banyak juga orang-orang umum yang berminat untuk ikut belajar.

Pemahaman bahwa pendidikan itu mahal dan sulit kini sudah berkurang bagi sebagian anggota kelompok mitra. Pokok bahasan pun disesuaikan sesuai permintaan kelompok mitra. Sesuai dengan hasil evaluasi respons yang telah dilakukan, dapat disarankan hendaknya programprogram pengabdian masyarakat seperti ini bisa dilaksanakan secara reguler dan berkala, melihat tingkat kebutuhan yang sangat tinggi akan pengenalan metode pembelajaran berbasis internet dan 
penggunaan media sosial kearah yang positif.

\section{SARAN}

Selanjutnya adalah pendampingan sejauh mana komunitas melakukan pembelajaran dan aplikasinya dalam kehidupan sehari-hari serta pengaruhnya terhadap peningkatan kemampuan Bahasa. Inggris

\section{UCAPAN TERIMA KASIH}

Terimakasih kepada kelompok mitra yaitu ibu-ibu PKK dan juga pihak aparat Desa Bojongcae yang telah bersedia bekerjasama mewujudkan kegiatan pengabdian masyarakat ini, dan sama-sama mau belajar atau menambah wawasan, guna terciptanya generasi muda yang lebih baik lagi.

\section{DAFTAR PUSTAKA}

Aditiya, A. (2016). Pengaruh Indikator Komposit Indeks Pembangunan Manusia Terhadap Pertumbuhan Ekonomi Provinsi Lampung. Jurnal Ekonomi Pembangunan Universitas Lampung. Retrieved from Http://digilib.unila.ac.id/24202/3

Darsyah , M. Y., \& Warsono, R. (2013). Pendugaan Ipm Pada Area Kecil Di Kota Semarang Dengan Pendekatan
Nonparametrik. Prosiding Seminar Nasional Statistika Universitas Diponogoro, Semarang, 18 Mei 2013, ISBN: 978-602-14387-0-1. Indonesia.

Farah, A., \& Sari , E. P. (2014). Modal Manusia dan Produktifitas . JEJAK, 1(7).Hal 22-24. doi: 10.15294/jejak.v7i1.3840

Hidayat, T., Rahmatan, H., \& Khairil. (2016). Pemanfaatan Media Pembelajaran Berbasis Internet Pada Konsep Sistem Peredaran Darah Terhadap Hasil Belajar Kognitif Siswa Pada Sma Negeri 1 Woyla. Jurnal Biotik, 1(4). ISSN: 2337-9812. Hal 1-7. Retrieved from: https://jurnal.araniry.ac.id/index.php/biotik/article/ view/1065/835

Rahman, K. (2016). Pengembangan Media Pembelajaran Berbasis Website Untuk Mata Pelajaran Programmable Logic Controller (Plc) Pada Smk Darussalam Makassar. Jurnal Inspiraton, 2(6). Hal : 105 -117. Retrieved from : https://jurnal.akba.ac.id/index.php/i nspiration/article/viewFile/2420/77 Rohdiani, F., \& Rakhmawati, L. (2017). Pengembangan Media Pembelajaran Berbasis Web Pada Mata Pelajaran Dasar Elektronika 
Di Smk Negeri 3 Jombang. Jurnal Pendidikan Teknik Elektro , 1 (6). Hal: 105 - 110. Retrieved from : Downloads/18212-22258-1PB.pdf.

Sugianto, Permadhi, Y. T., \& Juliannisa, I. A. (2018). Perencanaan Pembangunan Daerah Melalui Peran Partisipatif Pemerintah Desa Cibadak Dan Desa Bojongcae, Kecamatan Cibadak, Kabupaten Lebak, Provinsi Banten. Prociding AICEDC, Jember 4-5 Oktober 2018, E-ISBN 978-623-90312-0-6. Indonesia.

Suliswanto, M. S. (2010). Pengaruh Produk Domestik Bruto (PDB) Dan Indeks Pembangunan Manusia (Ipm) Terhadap Angka Kemiskinan Di Indonesia. Jurnal Ekonomi Pembangunan Universitas Brawijaya, 2(8). Hal : 357-366. doi :

https://doi.org/10.22219/jep.v8i2.3 $\underline{610}$

Todaro, M. P., \& Smith, S. C. (2013). Pembangunan Ekonomi . Jakarta: Erlangga. 